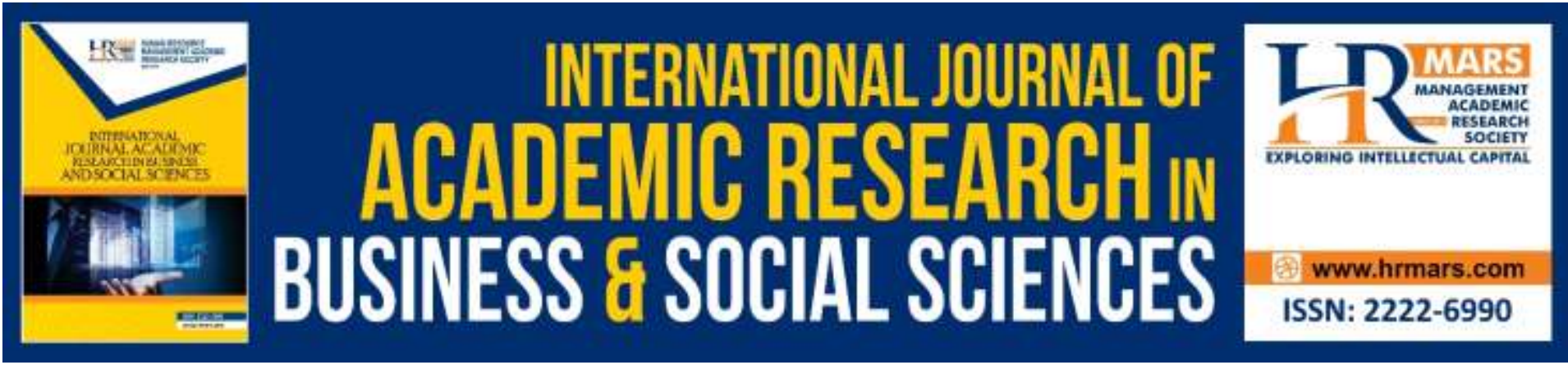

\title{
The Effect of Supportive Work Environment on Employee Retention at Malaysia Information, Communication, and Technology (ICT) Industry
}

Nurul Ezaili Alias, Nor Adibah Zailan, Arnida Jahya, Rozana Othman, Aqilah Nadiah Md Sahiq

To Link this Article: http://dx.doi.org/10.6007/IJARBSS/v9-i8/6210

DOI: $10.6007 /$ IJARBSS/v9-i8/6210

Received: 02 June 2019, Revised: 17 June 2019, Accepted: 01 July 2019

Published Online: 23 August 2019

In-Text Citation: (Alias, Zailan, Jahya, Othman, \& Sahiq, 2019)

To Cite this Article: Alias, N. E., Zailan, N. A., Jahya, A., Othman, R., \& Sahiq, A. N. M. (2019). The Effect of Supportive Work Environment on Employee Retention at Malaysia Information, Communication, and Technology (ICT) Industry. International Journal of Academic Research in Business and Social Sciences, 9(8), 61-77.

\section{Copyright: (C) 2019 The Author(s)}

Published by Human Resource Management Academic Research Society (www.hrmars.com)

This article is published under the Creative Commons Attribution (CC BY 4.0) license. Anyone may reproduce, distribute, translate and create derivative works of this article (for both commercial and non-commercial purposes), subject to full attribution to the original publication and authors. The full terms of this license may be seen at: http://creativecommons.org/licences/by/4.0/legalcode

Vol. 9, No. 8, 2019, Pg. 61 - 77

Full Terms \& Conditions of access and use can be found at http://hrmars.com/index.php/pages/detail/publication-ethics 


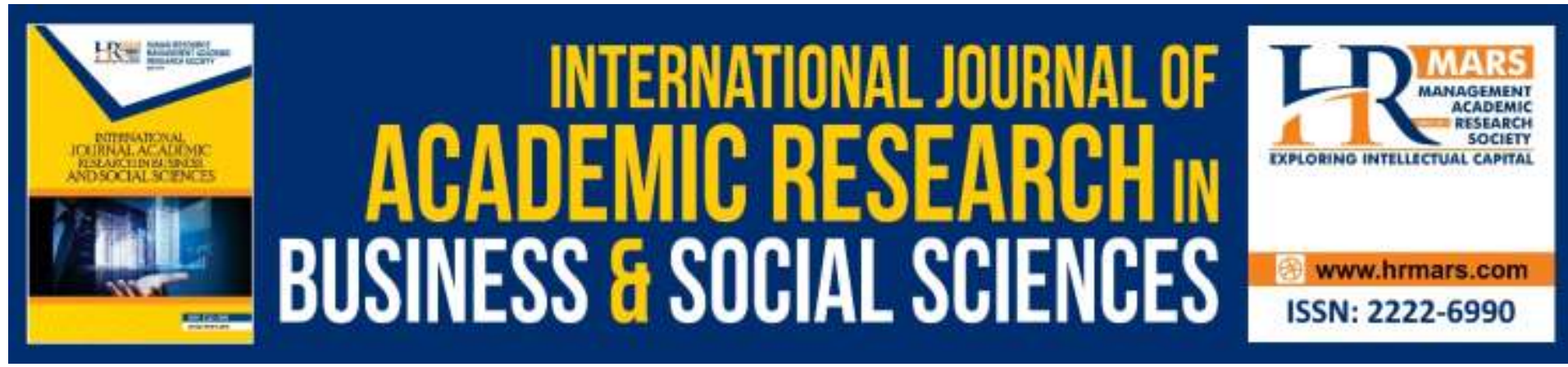

\title{
The Effect of Supportive Work Environment on Employee Retention at Malaysia Information, Communication, and Technology (ICT) Industry
}

\author{
Nurul Ezaili Alias, Nor Adibah Zailan, Arnida Jahya, Rozana \\ Othman, Aqilah Nadiah Md Sahiq \\ Faculty of Business and Management, Universiti Teknologi MARA, Cawangan Melaka
}

\begin{abstract}
The decreasing number of employee retention rate especially in the Information, Communication, and Technology (ICT) industry, either in local and global, cannot be exempted. Previous studies revealed that a supportive work environment is among the retainable factors. Thus, the purpose of this study examined the effect of supportive work environment on employee retention. There are three dominant predictors of a supportive work environment, namely organizational support, supervisory support, and job satisfaction that are hypothesized to have a positive and significant relationship with employee retention. A total of 257 questionnaires have distributed and 183 valid questionnaires have returned. The data collected are statistically analyzed and reported in descriptive statistics, frequency, Pearson correlation, and multiple regression analyses. The findings of the study confirmed that only supervisory support and job satisfaction, have a positive and significant relationship with employee retention. However, there is no significant relationship found between organizational support and employee retention among ICT employees.
\end{abstract}

Keywords: Organizational Support, Supervisory Support, Job Satisfaction, Employee Retention, Information Communication, and Technology (ICT)

\section{Introduction}

A decreasing rate of employee retention rate is becoming a major problem for every organization nowadays. The worse scenario is when talented employees voluntarily resigned their current position from the organization (Alias, Othman, Koe, Ridzuan, \& Krishnan, 2017). Further, if an employee leaves the organization voluntarily due to better offer or job dissatisfaction will influence other employees to make the same direction, thus setting off a phenomenon of turnover and focusing on initiatives to retain them from becoming a contagious in an organization always a major concern by organizational leaders (Gray, 2012). Furthermore, other than focusing on employee turnover rate, employee retention turns to be an indicator to the organization on their ability to initiate effective retention strategies and to retain their employees, especially in keeping the best performers (Ozolina-Ozola, 2014; Anvari, JianFu, and Chermahini, 2014). 
Organizational leaders nowadays are continuously reviewing and revising their retention strategies as the top priority action by organizations. According to McCullum (2010), stated that employee retention strategy becoming part of the human resource management function in the organization, and it is one of the manager's to-do-list. In 2011, also mentioned in Cardy and Lengnick-Hall's study, employee retention is one of the main strategies by organizational human resource management division since employees especially the valuable ones are the human capital that is contributing to a sustainable competitive advantage for an organization. Further, organizational leaders believe employee retention strategy also contributing to the achievement of organizational goals and objectives and survive in the market for a long run (Lee, Hom, Eberly, and Li, 2018).

As human capital cannot be imitated and easily be replaced, every organization must have a unique retention strategy depending on the talent pool they have (McCullum, 2010). Nazia and Begum (2013) stated that there are 3Rs (reward, recognition, and respect) to retain employees, and these $3 R$ s also have the ability to improve the pleasurable work environment including effective and efficient performance, better attendance and a higher return on investment. In a recent study, Kundu and Lata (2017) researched seven predictors to employee retention, and there are challenging work, learning opportunities, good relationships with co-workers, compensation, and appreciation of the current performance, recognitions, work-life balance, and finally an effective method of communication.

Since the 2000s, researchers and practitioners believed that by providing a better and conducive work environment, it shown a part of organizational support to the employees and, hence retained talented employees (Guchait and Cho, 2010; Ghosh and Sahney, 2011). The human resource manager also faced the issue of employee leaving the organization due to retirement or voluntarily resignation either in government and private industry, specifically, skill shortage in various industries, as such information, communication, and technology, manufacturing, mining, construction, health, allied medical service, and engineering. Thus, this issue also contributed to additional costs, especially on recruitment and selection, job analysis and job design, and training and development programs (Perryer, Jordan, Firns, and Travaglione, 2010). In conclusion, the avoidance of employee turnover rate can affect the positive and negative aspects of individuals, society, and organizations. Hence, organizations must actively engage with employee retention in their strategic endeavor to remain competitive in the employment market.

The importance of building a supportive work environment is to attract potential candidates as well as to retain valuable employees. For instance, supportive relationship with other colleagues (Newman, Thanacoody and Hui,2011), focusing to improve underserved areas in order to readily face continuous challenges and competitive work environment (Juhdi, Pa'wan, and Hansaram, 2013) and where employees work in an environment where they can perform their tasks and duties in a peaceful and safe work environment (Danish, Ramzan, and Ahmad, 2013). In addition, DeLong (2015) proposed several factors of a supportive work environment, there are work pressure, the participation of employees in the decision-making process, managerial control, a culture of teamwork, supervisory support, task orientation, autonomy, comfortable working environment, work under pressure, creative and innovative, and clarity. In a recent study, Kundu and Lata (2017) further researched on supportive work environment and the factors are support from supervisor, organizational, and peer. 
Consequently, those factors of supportive work environment mentioned in previous findings were found to improve engagement and retention level among workers (Kundu and Lata, 2017; Yang, 2013; Ganz and Toren, 2014; Zhang, You, Liu, Zheng, Fang, Lu, and Bu, 2014), job satisfaction (Tnay, Othman, Siong, \& Lim, 2013; Lambrou, Merkouris, Middleton, and Papastvrou, 2014), and employees feel supported and encouraged (Prieto and Perez-Santana, 2014). Previous researches revealed that the higher the level of organizational support, supervisory suport, and job satisfaction, the higher the level of employee retention rate (Islam et al., 2018; Gevrek, Spencer, Hudgins, and Chambers, 2017; Ramalho, Luiz, De, 2018; Adikiah, 2018). However, in other studies on perceived supervisory support toward employee retention, it is found that there is a no significant relationship between variables (Alias, Mat Roni, Merga, and Ismail, 2017).

According to Cronley and Kim (2017), organizations can be considered as a poor organization if they failed to overcome the continuous issue of high voluntary employee turnover rates. The issues of poor retention rate happened in various industries and industries, globally and locally. For instance poor retention rates among ICT professionals skill (Eva, 2017), technology (software) professionals as reported in LinkedIn's global survey has the highest employee turnover rate with 13.2\% (Corner, 2018), ICT industry's employees (Ramalho, Luiz, De, 2018; Adikiah, 2018), global professional services firm's employees (Chin, 2018), as well as manufacturing business' employees (Eugene, 2015).

Information, communication, and technology (ICT) industries cannot be exempted from facing a poor retention rate. There are also various reasons for their decision not to stay longer in the organization, as such marketable and high value in terms of compensation and benefits, its particularities and shortage of labor, and due to highly competitive of skills and expertise among ICT employees (Alias et al., 2017), specifically professionals skill (Eva, 2017; Ramalho, Luiz, De, 2018; Adikiah, 2018). Anvari et al. (2014) and Adikiah (2018) also stressed that due to the increasing needs of ICT advancement in business activities and increasing demands of ICT in the system, websites, mobile applications, marketing strategies for the products and services, forced the rival firms to offer more attractive remuneration packages to attract and recruit potential employees and professionals.

In facts, ICT firms in globally and in Malaysia cannot be escaped from facing the critical issue of poor retention rates among their employees. Due to inconsistent findings by previous studies, this study has examined the effect of the supportive work environment (organizational support, supervisory support, and job satisfaction) on employee retention level among employees in ICT firms in Malaysia.

\section{Literature Review \\ Employee Retention}

Employee retention is defined as the organization's initiatives and efforts to sustain current employees and to maintain a good working environment (Wickramasinghe, 2010), an encouragement process by organizations to ensure completion of a project by remaining the organizational human capital at a long-time period (Sandhya and Kumar, 2011) and show the organization's ability to keep its employee (Yang, 2013). According to George (2015), employee retention is measuring the level of intention to stay and it was seen to be the opposite of turnover intention. Further, failures to retain professional talents lead to higher recruitment, selection, replacement costs of new employees (George, 2015), and disruptions of organizational communities, lower productivity, and reduce employees' morale to stay 
longer due to loss of employees, (Dechawatanapaisal, 2018). Furthermore, not only higher costs of replacement of a new employee but organizations also will bear the costs of training programs to train new employees well versed with their new working environment, and the most valuable thing is the times that they will spend to attend the training programs (Dechawatanapaisal, 2018).

Nevertheless, losing employees contribute to higher costs to organizations but even worse if the loss of employees is also among the best performers. In retaining employees, especially the best performers, they are demanding with different needs and wants in their employment. However, small organizations struggle more than large organizations because they have to compete with large organizations' competitive offers to job seekers in the employment market. As a matter of fact, attracting the best performers must with a more attractive compensation and benefits package than their previous organization (Ghosh, Satyawadi, Joshi, and Shadman, 2013).

Some of the employees stay a longer period in an organization due to an effective supportive work environment, and among all findings, these are the factors of a supportive work environment contributed to a higher retention rate. The factors supportive work environment was attractive compensation and benefits offers, opportunity to be promoted, a positive and supportive working environment (Perryer et al., 2010; George, 2015, Lee et al., 2018), appreciation and recognitions to current best performers (Ghosh et al., 2015; Lee et al., 2018), organizational culture, opportunities to training and development, effective supervision, supervisory and social support, challenging assignments/tasks, open-door policy, a good relationship and socialization with co-workers, balance between professional and personal stuffs, effective communication tools, distributive justice, autonomy (George, 2015), shared values and culture beliefs (Dechawatanapaisal, 2018), and work-life balance (Lee et al., 2018).

Thus, the significant factor that can influence employee retention is an effective supportive work environment. In conclusion, employee retention is one of the organization's top concern to become preferable employers among its competitors (Ghosh et al., 2015).

\section{Organizational Support and Employee Retention}

The earliest definition of organizational support by Eisenberger, Hungtington, and Sowa (1986) is the worldwide employees' belief in how they value their organization's concern about their physical and mental well-being. Then in latest definition by Suifan, Abdallah, and Janini (2018), organizational support can be described as how an organization values and care about their employees' welfare and perceived organizational support can be explained as the level of employees' sensitivity and judgment on how organizations valued and recognized their contributions to the organizational success. Organizational support also as an important predictor to build a strong relationship between employer-employee through showing their supports by more concern and attention about their well-being (Kunasegaran, Ismail, Mohd Rasdi, Arif Ismail, and Ramayah, 2016).

The explanation of organizational support is explained under the perceived organizational theory (POS), where the theory theorized that the more employees received from the employers, the more efforts will be contributed by the employees, hence their performance increases. Employees will also show the same value of supports as shown by the employers. They feel obliged and responsible to assist the management in achieving the mission and vision of the organization (Suifan et al., (2018). Further, the theory also theorized 
that the higher the perceived organizational support, the higher the employees' attachment level as well as, affecting the level of their intention to stay with the organization (Islam, Ali, and Ahmed, 2018).

Islam et al. (2018) also argued that organizational support is an option of practice by an organization to choose whether to prioritize it or not. Hence, if organizations believed in practicing high organizational support, they will gain their workforce' support. According to Arnold and Dupre (2012), the higher the perceived organizational support, will make employees feel they are valuable and worth for the organization, and they also feel having a good experience and moment working in the organization. However, if the organizations are procrastinating their employees especially the talented employees, they will easily feel undervalued and demotivating them to perform better for the organization, as well as lead to negative emotions and not gaining anything but stress.

In Tuzun and Kalemci's (2012) study, the concept of perceived organizational support as one of the predictors to turnover intention has been studied and researched by previous researchers and practitioners. Immediate superiors or managers play an important role in an employee's decision to leave or stay in the organization. The study also explained the POS theory that the higher the practice of organizational support, it will make the employees feel they will be rewarded for their exceptional efforts, and increase their decision to stay (Tuzun and Kalemci, 2012). This reciprocal relationship is under social exchange theory (SET) that has gained prominence as a framework to further understand the exchange behavior between employee and employer (Tuzun and Kalemci, 2012).

A study among nurses from fourteen large hospitals in Pakistan resulted in increasing the positive emotional bonds between employer-employee if the employer shows the organizational support, and in returns, it reduced their decision to stay (Islam et al., 2018). On the other hands, a study in five multinational corporations in China among MNCs' employees found that perceived organizational support will increase the intention to stay among them (Newman et al., 2011). In Western, South Asia, and East Asia studies, it confirmed that there is a positive and significant relationship between perceived organizational support and employee retention (Newman et al., 2011; Islam et al., 2018).

In conclusion, previous researches have statistically analyzed and found that there is a positive relationship between perceived organizational support and employee retention. The higher the perceived organizational support, the higher the employee retention rate (Alexander Hamwi et al., 2011). In other studies on perceived organizational support and turnover intention, it found that there is a negative and significant relationship between perceived organizational support and turnover intention, which means that the higher the perceived organizational support, the lower the employee turnover intention rate (Tuzun and Kalemci, 2012). Therefore it is hypothesized that; Hypothesis 1 (H1): There is a significant and positive relationship between organizational support and employee retention.

\section{Supervisory Support and Employee Retention}

A supervisor is a role in an organization that represents the organizational management to supervise the subordinates closely and keep communicating the goals and values of their organization. The supports from the supervisors play an important part in physically expressing and indicating a supportive work environment in an organization (Suifan et al., 2018). Supervisory support can translate the level of employees' perceive on the behavior of appreciation of their contributions and care about their well-being that given by their 
immediate supervisors (Eisenberger, Stinglhamber, Vandenberghe, Sucharski and Rhodes, 2002).

Supervisory support measured through the perceived supervisory support (PSS), and it refers to employees' opinion on the extent of how their supervisor value their efforts and care about their well-being. Indirectly, it expressing organizational support when they received this kind of support, and in returns, employees feel gratified to assist the supervisor in achieving the goals and objectives (Tuzun and Kalemci, 2012). Perceived supervisory support is also a supervisor's non-work obligation but a discrete policy practice by organizations where all supervisors will keep in their mind to attend their subordinates at their very best (Alexander Hamwi et al., 2011).

The role that a supervisor should pay more attention is the assistance in providing resources and ensuring they can perform and complete the individual or group tasks, and as well as keep communicating with the subordinates to demonstrate stronger support from the organization. The higher the level of perceived supervisory support, an employee will loyal to serve the same supervisor, hence, at the same time, they will feel attached and stay at a longer period with the organization (Tuzun and Kalemci, 2012). Supervisory support has gained prominence topic in past literature, and it is significantly related to organizational outcomes, including employee turnover (Newman et al., 2011).

Newman et al. (2011) stressed that employees view their supervisors as a mentor and tend to exhibit greater loyalty towards supervisor than the organization, this is because loyalty to a person, rather than commit to an organizational system seemed to be greater importance to employees. This reciprocal relationship under the social exchange theory (SET) framework that explains further the understanding of the exchange behavior between employee and employee. The theory also theorizes the supervisory support inducing a higher supportive work environment from the organization to retain employees (Newman et al., 2011).

A previous study by Tuzun and Kalemci (2012) on the insurance industry's employees in Turkey found that perceived supervisory support is significantly related to employee retention. Further, Newman et al.'s (2011) study on five MNCs among employees in China found that there is a positive and significant relationship between perceived supervisory support and employee retention. Recently, in Alias et al.'s (2017) study, researched using statistical analysis, SPSS software, among 581 IT employees in Malaysia found that there is a positive and significant relationship between managerial support and employee retention. On the other hand, in another study by Alias et al., 2017), using SEM analysis, among 581 IT employees, the study revealed managerial support has no significant role in keeping the employees working with the organization.

In conclusion, it cannot be deniable that supervisory support plays an important predictor of a supportive work environment that statistically increase the level of employees' intention to stay with the organization (Newman et al., 2011; Gevrek, Spencer, Hudgins, and Chambers, 2017). Therefore, it is hypothesized that; Hypothesis 2 (H2): There is a positive and significant relationship between supervisory support and employee retention.

\section{Job Satisfaction and Employee Retention}

Job satisfaction refers to how employees value their jobs according to their likable factors (Spector, 1997). According to Cronley and Kim (2017), job satisfaction is a pleasurable emotional state that an employee evaluates and perceive from what they have received from 
the job in facilitating them to achieve the job goals and values. Job satisfaction also is defined as an evaluative of judgment, either positive or negative, that employees make towards what they experience in their job and work environment (Cronley and Kim, 2017). From the psychological perspective, job satisfaction is how employees feel about different facets and sections they receive in the job (Suifan, Diab, and Abdallah, 2017). The importance of job satisfaction has been largely emphasized because it has a relationship with organizational outcomes including job performance, organizational performance, customer loyalty and employee retention (Lu, Lu, Gursoy, and Neale, 2016).

Job satisfaction is a reflection of how employees value and judge what they receive from the organizational context (Ramalho et al., 2018). Previous research revealed that the higher the job satisfaction level, the higher the employee retention rate. It reveals that satisfied employees with the job with influence to a positive attitude and work outcomes (Suifan et al., 2017; Ramalho et al., 2018). Positive attitudes are constituting to the interdependence of both affective and cognitive, which means their feelings and thinking toward organizational context (Huang, Chen, Liu, and Zhou, 2017). Based on previous researches, cognitive job satisfaction refers to employees cognitively think about the nature of their job as such working conditions, opportunities, outcomes of their work, while affective job satisfaction refers to employee feelings about what they like and hate toward their job (Huang et al., 2017). Job satisfaction is a motivation factor that constitutes positive outcomes, and the factors included payment, relationship with co-workers, relationship with immediate superiors, promotion opportunities and the tasks itself (Othman, Alias, Ariadi, Abdullah, Koe, Ismail, \& Ridzuan, 2017; Ramalho et al., 2018).

As revealed by previous studies, job satisfaction also as one of the supportive work environment predictors and statistically influenced turnover intention among workers (Ferreira, Martinez, Lamelas, and Rodrigues, 2017). According to Huang et al. (2017), job satisfaction is a critical predictor of turnover intention. Further, Tnay et al.'s (2013) study among Australian pathology company's employees found that job satisfaction as one of the supportive work environment predictors and has a positive and significant relationship with employee retention. Romaldo et al. (2018) conducted a study on job satisfaction factors on turnover intention among ICT professionals and found that there is a relationship between variables. Further, Suifan et al. (2017) conducted a study among Jordan Airline's employees and revealed that the high employee turnover is caused by job dissatisfactions, especially the mistreatment of interpersonal relationship in the organization. Therefore it is hypothesized that; Hypothesis 3 (H3): There is a positive and significant relationship between job satisfaction and employee retention. 


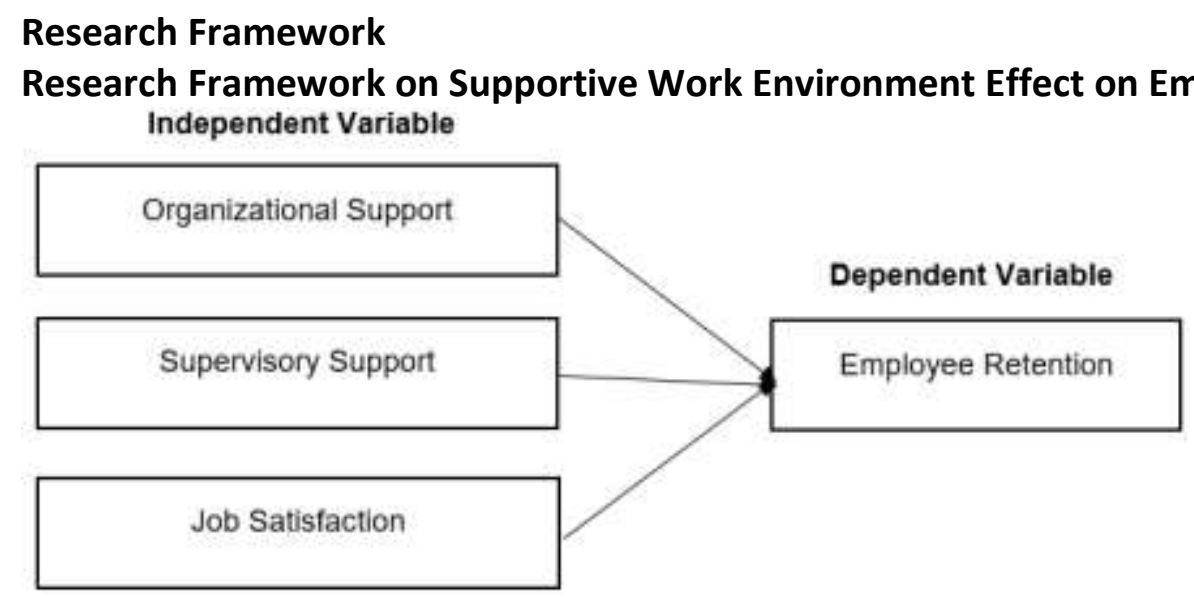

Fig 1 Research Framework

\section{Research Methodology}

This purpose of this study is to examine the effect of the supportive work environment (organizational support, supervisory support, and job satisfaction) on employee retention among employees at information, communication and technology firms in Malaysia. The study has self-administered the questionnaires to all employees, and from a total of 257 questionnaires have been conveniently distributed, only 183 valid questionnaires have returned to the researchers, and this represents $71 \%$ average of response rate. A response rate that is above $70 \%$, able to represent the data findings to the whole population (Stephen, Carol, Qing and James, 2006)

The questionnaire developed in this study consists of 47 measurement items and divided into five sections. Section A includes the demographic detail of respondents. Section $B, C$, and $D$, are related to the independent variables of the study, namely organizational support, supervisory support, and job satisfaction. The last section is section $E$ related to the dependent variable, namely, employee retention. The measurement items in this study adopted from previous and established instruments. Specifically, it adopted 11 items from Dechawatanapaisal (2018) to measure perceived employee retention. The supportive work environment constructs contained three predictors (organizational support, supervisory support, and job satisfaction); thus, it adopted 29 items from Akgunduz \& Sanli (2017), Burns (2016), and Leticia (2010) to measure the three predictors of employee retention. Finally, there are seven items on the demographic profile that is developed by the researchers.

The internal consistency reliability analysis of all measurement items was assessed through Cronbach alpha $(\alpha)$ and revealed that all the scales adopted in this study were accepted with alpha's value between $0.781<\alpha<0.954$. Multivariate statistical analysis using Statistical Package for the Social Science (SPSS) software was carried out to analyze the data collected. The findings in this study reported through analyses of descriptive statistics, frequency, Pearson correlation, and multiple regressions analysis. 
Findings

Respondents' Background

Table 1 Frequency Analysis

\begin{tabular}{|c|c|c|c|}
\hline \multicolumn{2}{|l|}{ Item } & Frequency & Percentage \% \\
\hline \multirow[t]{2}{*}{ Gender } & Male & 85 & 46.4 \\
\hline & Female & 98 & 53.6 \\
\hline \multirow[t]{5}{*}{ Age } & $18-28$ & 96 & 52.5 \\
\hline & $29-39$ & 68 & 37.2 \\
\hline & $40-50$ & 15 & 8.2 \\
\hline & $51-60$ & 4 & 2.2 \\
\hline & 61 and Above & 0 & 0 \\
\hline \multirow{6}{*}{$\begin{array}{l}\text { Education } \\
\text { Level }\end{array}$} & SPM (Secondary & 4 & 2.2 \\
\hline & School) & & \\
\hline & Diploma & 61 & 33.3 \\
\hline & Bachelor's Degree & 100 & 54.6 \\
\hline & Master's Degree & 17 & 9.3 \\
\hline & Others & 1 & 0.5 \\
\hline \multirow{4}{*}{$\begin{array}{l}\text { Years } \\
\text { Service }\end{array}$} & $<1$ Year & 40 & 21.9 \\
\hline & 1-3 Years & 56 & 30.6 \\
\hline & 3-6 Years & 42 & 23 \\
\hline & 6 Years and Above & 45 & 24.6 \\
\hline \multirow[t]{9}{*}{ Division } & A & 1 & 0.5 \\
\hline & B & 1 & 0.5 \\
\hline & C & 12 & 6.6 \\
\hline & $\mathrm{D}$ & 3 & 1.6 \\
\hline & $E$ & 80 & 43.7 \\
\hline & $\mathrm{F}$ & 52 & 28.4 \\
\hline & G & 24 & 13.1 \\
\hline & $\mathrm{H}$ & 9 & 4.9 \\
\hline & I & 1 & 0.5 \\
\hline
\end{tabular}

$\mathrm{N}=183$

Table 1 shows the frequency analysis of the respondent's demographic profile. The researched firm is a leading information and communication technology (ICT) solutions and services company with its core purpose to improve quality of life of the communities it serves, through long-term value creation based on exceptional acumen and astute leadership. It consists of several sub-companies and nine main divisions that focus on building a business, which consists of healthcare management systems, redefining core banking solution, empowering digital with technology, telco services, managed services, integration services, and software development requirements. The organization is located in the Southern Region of Malaysia and established since 2013.

Out of 183 respondents, majority of the respondents are female with $(n=98,53.6 \%)$, and the rest were male with $(n=85,46.4 \%)$. The highest majority of the respondent's age was between 18-28-year-old ( $n=96,52.6 \%)$, followed by $29-39$ year old $(n=68 ; 37.2 \%) 40-50$ year 
old $(n=15 ; 8.2 \%)$, and $50-60$ year old $(n=4,2.2 \%)$. Further, majority of the respondents hold a degree $(n=100 ; 54.6 \%)$, followed by a diploma $(n=61 ; 33.3 \%)$, masters degree $(n=17,9.3 \%)$, and only 4 respondents are primary graduates (SPM) with $2.2 \%$, while the remaining $(n=1$, $0.5 \%$ ) of respondent qualified from other education level.

In addition, majority of respondents' tenure was between $1-3$ years ( $n=56 ; 30.6 \%)$, followed by $>6$ years $(n=45 ; 24.6 \%), 3-6$ years year $(n=42 ; 23 \%)$, and $<1$ year $(n=40 ; 21.9 \%)$. Finally, due to private and confidential issue, the firm only allowed to reveal the division as division $A$ until I. The highest of respondents were from Division $E(n=80 ; 43.7 \%)$, Division $F$ ( $n=52 ; 28.4 \%)$, Division $G(n=24 ; 13.1 \%)$, Division $C(n=12 ; 6.6 \%)$, Division $H(n=9 ; 4.9 \%)$, Division $D(n=3 ; 1.6 \%)$, and Division $A, B, I(n=1 ; 0.5 \%$ respectively). Hence, based on the frequency analysis of respondents' age, academic qualification and tenure, it can be claimed that half of the respondents are a degree holder, with a young age between 18-28-year-old, and have working experience for less than 3 years.

\section{Mean, Correlations and Regressions Analyses}

Table 2 Mean, standard deviation and correlations

\begin{tabular}{llll}
\hline & $m$ & $S D$ & $\begin{array}{l}\text { Pearson } \\
\text { Correlation, } r \\
\text { Job Stress }\end{array}$ \\
\hline Employee Retention & 3.52 & 0.67 & 1 \\
Organizational Support & 3.54 & 0.72 & $.603^{* *}$ \\
Supervisory Support & 3.48 & 0.67 & $.606^{* *}$ \\
Job Satisfaction & 3.60 & 0.52 & $.632^{* *}$ \\
\hline
\end{tabular}

Sig. (2-tailed); $\mathrm{N}=183$

The descriptive statistics analysis findings; mean and standard deviation shown based on table 2. The highest mean value is the dependent variable, which is employee retention with $m=3.60 ; S D=0.52$. Then followed by the independent variables of supervisory support, organizational support, and job satisfaction with $m=3.54 ; S D=0.72, m=3.52 ; S D=0.67$, and $m=3.48 ; S D=0.67$ respectively. In average, all variables items of the study were agreed by the respondents.

In order to determine the correlation between variables, predictors of the supportive work environment (as independent variables) and employee retention (dependent variable), Pearson correlation, coefficient $(r)$, was performed in Table 2 . It reveals that all variables (organizational support, supervisory support, job satisfaction, and employee retention) were a significant, positive, and strong relationship between variables $(0.603 \leq r \leq 0.632$; sig $<0.01)$. It also confirmed that there is no multicollinearity issue, as the greatest $r$-value was 0.632 . 
Table 3 Multiple Regression Analysis

\begin{tabular}{lll}
\hline $\begin{array}{l}\text { Independent } \\
\text { Variable }\end{array}$ & $\begin{array}{l}\text { Standardized } \\
\text { Coefficients (Beta) }\end{array}$ & Sig. \\
\hline $\begin{array}{l}\text { Organizational } \\
\text { Support }\end{array}$ & 0.190 & 0.059 \\
\hline $\begin{array}{l}\text { Supervisory } \\
\text { Support }\end{array}$ & 0.203 & 0.044 \\
\hline Job Satisfaction & 0.326 & 0.001 \\
\hline F-Value & 47.493 & \\
\hline Significant & 0.00 & \\
\hline R-Square & 0.443 & \\
\hline $\begin{array}{l}\text { Note: *P<0.05, ANOVA, Sig. at 0.00 } \\
\text { a. Predictors: (Constant), Organizational Support, Supervisory Support, Job }\end{array}$ \\
$\begin{array}{l}\text { Satisfaction } \\
\text { b. Dependent Variable: Employee Retention }\end{array}$
\end{tabular}

The hypotheses of this study were hypothesized through multiple linear regressions, as presented in Table 2 . The table of multiple regression analysis above indicated that the model was statistically significant, as the F-value obtained was 47.493 (sig. <0.01). The $R$ squared value attained was 0.443 , and this explained that all independent variables of this study explained the variance in employee retention as much as $44.3 \%$. Thus, the other $55.7 \%$ of the variance in employee retention can be explained by other factors that are out of the scope of the study.

There are three objectives of this study, there are to examine the effect of the supportive work environment (1. organizational support, 2. supervisory support, and 3. job satisfaction) on employee retention level among employees in ICT firms in Malaysia. In order to meet the objectives, three hypotheses have been tested. The results of multiple linear regressions revealed that all the independent variables; organizational support, supervisory support, and job satisfaction were found to have a positive relationship with the dependent variable; job stress. However, only 2 independent variables shown a positive and significant relationship with dependent variable, there are supervisory support $(\beta=0.203$; sig.<0.05), and job satisfaction $(\beta=0.326$; sig. $<0.01)$, while 1 independent variable, which is organizational support ( $\beta=0.190$; sig.>0.05) had no significant relationship with job stress. From the multiple regression analysis, it confirmed that job satisfaction has the strongest influence on employee retention with the highest beta value $(\beta=0.326$; sig.<0.01). Therefore, the results of the hypotheses proved that only $\mathrm{H} 2$ and $\mathrm{H} 3$ were supported, while $\mathrm{H} 1$ was not supported.

\section{Discussion}

The purpose of this research is to identify the supportive work environment effect on employee retention at ICT firms in Malaysia. Based on previous researches, there were several predictors of supportive work environment influenced to employee retention, including organizational support, supervisory support, and job satisfaction. Therefore, there are three 
hypotheses for this research that requires validation. Based on the multiple regression analysis findings, it reveals hypothesis $1(\mathrm{H} 1)$, there had no significant relationship between organizational support and employee retention with beta value $(\beta=0.19, p>0.05)$. This finding claimed that the items for organizational support do not affect the intention to stay among employees in ICT firms. From the mean analysis of each item in this variable, ICT employees and professionals can work on their own based on the autonomy granted by the organization. This is due to their nature of work that do not need any assistance from the organization or superiors to complete their tasks. Further, the respondents also preferred a workstation that is fully furnished, convenience, and complete resources.

Based on the findings, it is found that hypothesis $2(\mathrm{H} 2)$ was accepted and revealed that there is a positive and significant relationship between supervisory support and employee retention $(\beta=0.203 p<0.05)$. One of the support that ICT employees preferred more in the workplace is the response they receive from the supervisors/ managers on their contributions in the division/ organization and care about their well-being (Eisenberger et al., 2002). As found in the mean analysis findings of each item in this variable, ICT employees preferred their supervisors to foster genuine and trusting relationships, subordinate's achievements, growth, and development, solving the mistakes into productive development opportunities, keep communicating with subordinates, helps subordinates get the resources to do the job, and other factors related to employees' well-being. The more support receives from the supervisors/ immediate superiors, the higher the intention to stay among ICT employees in the organization. Supervisory support has also been found to increase employee intentions to stay longer with the organization in the previous study by Newman et al. (2011) and Gevrek et al. (2017).

Finally, hypothesis $3(\mathrm{H} 3)$ of the study hypothesized that there is a positive and significant relationship between job satisfaction and employee retention, and it revealed hypothesis $3(\mathrm{H} 3)$ of the study is accepted with beta value $(\beta=0.326, p<0.01)$ and according to Tnay et al. (2013), perceived job satisfaction as a predictor to a more supportive work environment, especially among ICT employees. According to the study's mean analysis, it is found that employees who worked in ICT companies are more satisfied if they provided by a promising career development opportunities, attractive financial and non-financial rewards, good term of relationship with co-workers, and as well as a satisfied nature of work and environment. Thus, the more satisfied employees on their jobs, the more determination they have to remain longer in a single organization. This finding was also similar to Romalho et al. (2018) and Ferreira et al. (2017).

\section{Recommendation}

From the findings of this research, there are few recommendations for future researcher and practitioner's improvement. Future research should seek other variables that can strengthen the model of supportive work environment effect on employee retention. The R-square value (R2) of this study was only $44.3 \%$ of the variance explained employee retention, while the remaining $55.7 \%$ is representing by other variables. For instance, peer-group interaction and perceived climate (Kundu and Lata, 2017).

For the organizations, especially in ICT industries, as job satisfaction was the strongest predictor influenced employee retention, providing better pay and fringe benefits plan will increase their level of job satisfaction. According to Tnay et al. (2013), compensation and benefits packages are the most preferred predictor to stay longer among employees. Based 
on the descriptive statistics analysis (mean \& SD value) on measurement items in job satisfaction survey section of this study, an individual employee in ICT firms preferred more financial and non-financial rewards provided by the organization. While providing career development opportunities, comfortable nature of work, and establish a good relationship with coworkers also made them satisfied and stay longer with the organization.

Finally, the findings also found supervisory support is one of the most preferred predictors to a supportive work environment that effect on employee retention in ICT firms. Based on the descriptive statistics analysis findings in the supervisory support section, again it is found that employees in ICT firms more preferred if their supervisors/ managers reward and recognize their excellence performance so that they will feel more valued in the organization. Further, as ICT employees and professionals' nature of work is more on dealing with computers or gadgets, they preferred the management offered them more flexible work schedule and more amount of autonomy to perform their tasks or projects. This benefits will make them stay longer in the organization. Other than that, supervisors must establish a genuine and trusting relationship in the team, as well as routinely communicates with their co-workers. It is because ICT employees' nature of work is all based on projects, so every team is assigned must be genuine and trusted, so they can trust each other and perform at their very best conditions. Lastly, support their professional growth and development also become their factors to stay longer in a single organization.

\section{References}

Adikiah, S. K. (2018, October 20). The most in demand job. Retrieved from https://www.humanresourcesonline.net/the-most-in-demand-job/

Akgunduz, Y., \& Sanli, S. C. (2017). The effect of employee advocacy and perceived organizational support on job embeddedness and turnover intention in hotels. Journal of Hospitality and Tourism Management, 31, 118-125. https://doi.org/10.1016/j.jhtm.2016.12.002.

Alias, N. E., Mat Roni, S., Merga, M. K., \& Ismail, I. (2017). Rethinking of talent management practices as an employee retention strategy in emerging economy. In The proceedings of 2nd Business Doctoral and Emerging Scholars Conference, At ECU Joondalup Campus Perth, Australia. (pp. 144-151).

Alias, N. E., Othman, R., Loon, K. W., Ridzuan, A. R., \& Krishnan, R. (2017). Towards Effective Employee Retention Strategy: Implementation of Talent Management in Information, Communication and Technology Companies. Advanced Science Letters, 23(8), 7857-7860.

Anvari, R., JianFu, Z., \& Chermahini, S. H. (2014). Effective Strategy for Solving Voluntary Turnover Problem among Employees. Procedia - Social and Behavioral Sciences, 129, 186190. https://doi.org/10.1016/j.sbspro.2014.03.665.

Hamwi, A. G., Rutherford, B. N., \& Boles, J. S. (2011). Reducing emotional exhaustion and increasing organizational support. Journal of Business \& Industrial Marketing, 26(1), 4-13. https://doi.org/10.1108/08858621111097166.

Arnold, K. A., \& Dupré, K. E. (2012). Perceived organizational support, employee health and emotions. International Journal of Workplace Health Management, 5(2), 139-152. https://doi.org/10.1108/17538351211239171.

BICT Group SDN BHD. About. (n.d). Retrieved 2018, October 20, from https://www.bit.com.my/about/ 
Cardy, R. L. and Lengnick-Hall, M. L. (2011), "Will They Stay or Will They Go? Exploring a Customer-Oriented Approach to Employee Retention", Journal of Business and Psychology, Vol.26 No. 2, pp. 213-217.

Chin, C. L. (2018). The Influence of Job Satisfaction on Employee Turnover Intention in the Manufacturing Industry of Malaysia, 1(2), 53-63.

Corner, F. (2018) Software has the highest job turnover rate of any industry in 2017. Retrieved from https://www.techrepublic.com/article/software-had-the-highest-job-turnoverrate-of-an.y-industry-in-2017/

Cronley, C., \& Kim, Y. Kyoung. (2017). Intentions to turnover: Testing the moderated effects of organizational culture, as mediated by job satisfaction, within the Salvation Army. Leadership and Organization Development Journal, 38(2), 194-209. https://doi.org/10.1108/LODJ-10-2015-0227.

Danish, R. Q., Ramzan, S., \& Ahmad, F. (2013). Effect of Perceived Organizational Support and Work Environment on Organizational Commitment: Mediating Role of Self Monitoring. Advances in Economics and Business, 1(4), 312-317.

Dechawatanapaisal, D. (2018). Employee retention: the effects of internal branding and brand attitudes in sales organizations. Personnel Review, 47(3), 675-693. https://doi.org/10.1108/PR-06-2017-0193.

DeLong, R. S. (2015). Key Strategies for Retaining Information Technology Professionals. Proquest Dissertations and Theses.

Eisenberger, R., Hungtington, R. H. and Sowa, S. (1986), "Perceived Organizational Support", Journal o Applied Psychology, Vol. 71 No. 31, pp. 500-7.

Eisenberger, R., Stinglhamber, F., Vandenberghe, C., Sucharski, I. L. and Rhoades, L. (2002), "Perceived Supervisor Support: Contributions to Perceived Organizational Support and Employee Retention", Journal of Applied Psychology, Vol. 87 No. 3, pp.565-573. No. 3, pp. 635-672.

Eva, Y. (2017, October 20). Average job turnover for a person is $21 / 2$ years. http://www.thesundaily.my/news/2017/07/20/average-job-turnover-person.

Eugene, M. (2015, July 11). Why employees quit. https://www.thestar.com.my/business/businessnews/2015/07/11/whyemployees-quit/

Ferreira, A. I., Martinez, L. F., Lamelas, J. P., \& Rodrigues, R. I. (2017). Mediation of job embeddedness and satisfaction in the relationship between task characteristics and turnover: A multilevel study in Portuguese hotels. International Journal of Contemporary Hospitality Management, 29(1), 248-267. https://doi.org/10.1108/IJCHM-03-2015-0126.

Ganz, F., \& Toren, O. (2014). Israeli Nurse Practise Environment Characteristics, Retention and Job Satisfaction. Israel Journal of Health Policy Research, Vol. 3, pp. 3-7.

George, C. (2015). Retaining professional workers: What makes them stay? Employee Relations, 37(1), 102-121. https://doi.org/10.1108/ER-10-2013-0151.

Gevrek, D., Spencer, M., Hudgins, D., \& Chambers, V. (2017). I can't get no satisfaction: The power of perceived differences in employee intended retention and turnover. Personnel Review, 46(5), 1019-1043. https://doi.org/10.1108/PR-06-2015-0189.

Ghosh, K. and Sahney, S. (2011), "Impact of Organizational Sociotechnical System on Managerial Retention: General Linear Modelling Approach", Journal of Modelling in Management, Vol. 6 No. 1, pp. 33-59. 
Ghosh, P., Satyawadi, R., Joshi, J. P., \& Shadman, M. (2013). Who stays with you? Factors predicting employees' intention to stay. International Journal of Organizational Analysis, 21(3), 288-312. https://doi.org/10.1108/IJOA-Sep-2011-0511.

Gray, T. (2012). Walden University, Strategies to Reduce Voluntary Employee Turnover in Business Organizations.

Guchait, P. and Cho, S. (2010), "The Impact of Human Resource Management Practices on Intention to Leave of Employees in the Service Industry in India: The Mediating Role of Organizational Commitment", The International Journal of Human Resource Management, Vol. 21 No. 8, pp. 1228-1247.

Huang, S., Chen, Z., Liu, H., \& Zhou, L. (2017). Job satisfaction and turnover intention in China. Chinese Management Studies, 11(4), 689-706.

https://doi.org/10.1108/CMS-12-2016-0263.

Islam, T., Ali, G., \& Ahmed, I. (2018). Protecting healthcare through organizational support to reduce turnover intention. International Journal of Human Rights in Healthcare, 11(1), 412. https://doi.org/10.1108/IJHRH-03-2017-0012.

Juhdi, N., Pa'wan, F. and Hansaram, R. M. K. (2013), "HR Practices and Turnover Intention: The Mediating Roles of Organizational Commitment and Organizational Engagement in a Selected Region in Malaysia", The International Journal of Human Resources Management, Vol. 24 No. 15, pp.3002-3019.

Kunasegaran, M., Ismail, M., Rasdi, M. R., Arif Ismail, I., \& Ramayah, T. (2016). Talent development environment and workplace adaptation: The mediating effects of organisational support. European Journal of Training and Development, 40(6), 370-389. https://doi.org/10.1108/EJTD-07-2015-0060.

Kundu, S. C., \& Lata, K. (2017). Effects of supportive work environment on employee retention: Mediating role of organizational engagement. International Journal of Organizational Analysis, 25(4), 703-722. https://doi.org/10.1108/IJOA-12-2016-1100.

Lambrou, P., Merkouris, A., Middleton, N., \& Papastavrou, E. (2014). Nurses' perceptions of their professional practice environment in relation to job satisfaction: A review of quantitative studies. Health Science Journal, 8,298-317.

Lee, T. W., Hom, P., Eberly, M., \& Li, J. (Jason). (2018). Managing employee retention and turnover with 21st century ideas. Organizational Dynamics, 47(2), 88-98. https://doi.org/https://doi.org/10.1016/j.orgdyn.2017.08.004.

Leticia, A. S. (2010). Predicting Employee Retention. International Journal of Management Sciences, 4(1), 35-41.

Lu, L., Lu, A. C. C., Gursoy, D., \& Neale, N. R. (2016). Work engagement, job satisfaction, and turnover intentions: A comparison between supervisors and line-level employees. International Journal of Contemporary Hospitality Management, 28(4), 737-761. https://doi.org/10.1108/IJCHM-07-2014-0360.

Ma Prieto, I. and Perez-Santana, M.P. (2014), "Managing Innovative Work Behaviour: The Role of Human Resources Practices", Personnel Review, Vol. 43 No. 2, pp. 184-208.

McCullum, K. (2010). Talent Retention. Office pro, 70(6), 11.

Nazia, S. and Begum, B. (2013), "Employee retention practices in Indian corporate-a study of select MNCs", International Journal of Engineering and Management Sciences, Vol. 4 No. 3, pp. 361-368.

Newman, A., Thanacoody, R., \& Hui, W. (2011). The effects of perceived organizational support, perceived supervisor support and intra-organizational network resources on 
turnover intentions: A study of Chinese employees in multinational enterprises. Personnel Review, 41(1), 56-72. https://doi.org/10.1108/00483481211189947.

Othman, R., Alias, N. E., Ariadi, N. S., Abdullah, A., Loon, K. W., Ismail, S., \& Ridzuan, A. R. (2017). Employee Retention in Emerging Economy: A Case of Gen $Y$ in Malaysian Manufacturing Company. Advanced Science Letters, 23(8), 7637-7640.

Ozolina-Ozola, I. (2014). The Impact of Human Resource Management Practices on Employee Turnover. Procedia - Social and Behavioral Sciences, 156(April), 223-226.

https://doi.org/10.1016/j.sbspro.2014.11.178.

Perryer, C., Jordan, C., Firns, I., \& Travaglione, A. (2010). Predicting turnover intentions: The interactive effects of organizational commitment and perceived organizational support. Management Research Review, 33(9), 911-923.

https://doi.org/10.1108/01409171011070323.

Ramalho, L. C. M. D., Luiz, D. P. S., \& De, O. L. M. B. (2018). Organizational commitment, job satisfaction and their possible influences on intent to turnover. Revista de Gestão, 25(1), 84-101. https://doi.org/10.1108/REGE-12-2017-008.

Sandhya, K., and D. Pradeep Kumar. (2011). "Employee Retention by Motivation." Indian Journal of Science \& Technology 4.12 (2011): 1778-1782.

Spector, P., E. (1997). Job Satisfaction Application, Assessment, Cause and Consequences. California: Thousand Oaks: Sage Publications.

Stephen, A. S., Carol, S., Qing, C., James, J. J., (2006). How low should you go? Low response rates and the validity of interference in IS questionnaire research. Journal of the Association for Information Systems, 7(6), 351-414.

Suifan, T. S., Abdallah, A. B., \& Janini, A. M. (2018). The impact of transformational leadership on employees' creativity: The mediating role of perceived organizational support. Management Research Review, 41(1), 113-132. https://doi.org/10.1108/MRR-02-20170032.

Suifan, T. S., Diab, H., \& Abdallah, A. B. (2017). Does organizational justice affect turnoverintention in a developing country? The mediating role of job satisfaction and organizational commitment. Journal of Management Development, 36(9), 1137-1148. https://doi.org/10.1108/JMD-02-2017-0048.

Tnay, E., Othman, A. E. A., Siong, H. C., \& Lim, S. L. O. (2013). The Influences of Job Satisfaction and Organizarional Commitment on Turnover Intention. Procedia-Social and Behavioral Sciences, 97, 201-208.

Tuzun, I. K., \& Kalemci, R. A. (2012). Organizational and supervisory support in relation to employee turnover intentions. Journal of Managerial Psychology, 27(5), 518-534. https://doi.org/10.1108/02683941211235418.

Wickramasinghe, V. (2010). Impact of time demands of work on job satisfaction and turnover intention: Software developers in offshore outsourced software development firms in Sri Lanka. Strategic Outsourcing: An International Journal, 3(3), 246-255.

https://doi.org/10.1108/17538291011093820.

Yang, Y. (2013). Are Supervisory Feedback Messages a Motivational Factor To Enhance Employee Retention?, (December).

Zhang, L., You, L., Liu, K., Zheng, J., Fang, J., Lu, M., Bu, X. (2014). The association of Chinese Hospital Work Environment with Nurse Burnout, Job Satisfaction and Intention to Leave. Nursing Outlook, 62, 128-137. Vol.23 No. 2, pp. 84-92. 